\title{
Commercial operation of the biogas cogeneration set with the JMS 316 GS-B.LC GE JENBACHER type engine
}

\begin{abstract}
The paper discusses three years' commercial operation to date of the Biogas Cogeneration Set driven with the JMS 316 GS-B.LC GE JENBACHER type engine, which has been operating in the WARTA S.A. Sewage Treatment Plant of Czestochowa since the end of December 2008. The analysis covered the CHP Set's operation and shutdown times, number of start-ups and availability, electric energy and heat generation, and average hourly electric and thermal load; the Sewage Treatment Plant's electric energy and heat balance and the degree of coverage of its electric energy and heat demand by its own production; the unit biogas consumption by the CHP Set; the service work carried out on, and failures of the CHP Set; and the economic effects gained from the operation of the Set. The study is a continuation of the authors' previous publications $[3,6,7,8]$ and, jointly with them, constitutes a unique compendium of knowledge for future operators of CHP biogas sets in the form of a collection of actual operational data for one of the most representative biogas cogeneration sets operated in domestic sewage plants in terms of electric power (approx. $0.8 \mathrm{MW}$ ).

Key words: biogas engine, CHP - Combined Head and Power, industrial operation, waste treatment plant
\end{abstract}

\section{Eksploatacja przemysłowa biogazowego zespołu kogeneracyjnego z silnikiem GE JENBACHER typu JMS 316 GS-B.LC}

\begin{abstract}
$W$ artykule omówiono dotychczasowa, trzyletnia eksploatacje przemysłowa biogazowego zespotu kogeneracyjnego z silnikiem GE JENBACHER typu JMS 316 GS-B.LC pracujacego od końca grudnia 2008 r. w Oczyszczalni Ścieków WARTA S.A. w Częstochowie. Analizowano czas pracy i postojów zespołu CHP, liczbę rozruchów i jego dyspozycyjność, produkcję energii elektrycznej i ciepła, średnie godzinowe obciażenie elektryczne i cieplne zespołu CHP, także bilans energii elektrycznej $i$ ciepła oczyszczalni oraz stopień pokrycia zaporzebowania oczyszczalni na energię elektryczna $i$ ciepło produkcja własna, jednostkowe zużcie biogazu przez zespół kogeneracyjny, prace serwisowe i awarie zespołu kogeneracyjnego oraz uzyskane efekty ekonomiczne z eksploatacji tego zespolu. Praca jest kontynuacja wczesniejszych publikacji autorów [3, 6-8] i łacznie z nimi stanowi unikatowe kompedium wiedzy dla przyszlych eksploatatorów biogazowych zespołów CHP w postaci zbioru rzeczywistych danych eksploatacyjnych, jednego z najbardziej reprezentatywnych pod względem mocy elektrycznej (ok. 0,8 MW) biogazowego zespotu kogeracyjnego eksploatowanego w krajowych oczyszczalniach ścieków.
\end{abstract}

Słowa kluczowe: silnik biogazowy, energetyka skojarzona, eksploatacja przemysłowa, oczyszczalnia ścieków

\section{Introduction}

As early as in the seventies of the past century, the WARTA S.A. Sewage Treatment Plant of Czestochowa, and actually its predecessor - the WARTA S.A. Commercial Water Company, on the initiative of Prof. Karol Cupiał of the Institute of Internal Combustion Engines and Control Technology (presently, after the reorganization of the Faculty of Faculty of Mechanical Engineering and Computer Science, renamed to the Institute of Thermal Machinery of Czestochowa University of Technology, undertook Poland's first trials on the utilization of biogas, as a by-product of anaerobic sewage sludge fermentation, for supplying piston engine-driven gas cogeneration sets, and subsequently operated several biogas cogeneration sets started up by Czestochowa University of Technology $[1,2,4,5]$ for many years.

\section{The cogeneration set with the GE}

\section{JENBACHER JMS 316 GS-B.LC biogas engine}

At the end of December 2008, in the WARTA S.A. Sewage Treatment Plant of Czestochowa, the company KWE-Technika Energetyczna Sp. z o.o. of Bielsko-Biała,

\section{Wstęp}

Oczyszczalnia Ścieków WARTA S.A. w Częstochowie, a właściwie jej poprzedniczka Przemysłowa Spółka Wodna WARTA S.A. w Częstochowie, już w latach siedemdziesiątych ubiegłego wieku, z inicjatywy prof. Karola Cupiała z Instytutu Maszyn Tłokowych i Techniki Sterowania Politechniki Częstochowskiej (obecnie, po reorganizacji Wydziału Inżynierii Mechanicznej i Informatyki - Instytutu Maszyn Cieplnych) podjęła pierwsze w Polsce próby utylizacji biogazu - produktu ubocznego beztlenowej fermentacji osadów ściekowych przez jego wykorzystanie do zasilania gazowych zespołów kogeneracyjnych z silnikami tłokowymi, a następnie przez wiele lat eksploatowała kilka biogazowych zespołów kogeneracyjnych uruchomionych przez Politechnikę Częstochowską [1, 2, 4, 5].

\section{Zespół kogeneracyjny z silnikiem biogazowym GE JENBACHER JMS 316 GS-B.LC}

W końcu grudnia 2008 r. w Oczyszczalni Ścieków WARTA S.A. w Częstochowie firma KWE-Technika Energetyczna Sp. z o.o. z Bielska-Białej - Autoryzowany Przedstawiciel 
the authorized representative of GE JENBACHER Gas Engines Division in Poland, commissioned a modern biogas cogeneration set complete with a GE JENBACHER JMS 316 GS-B.LC engine of an electric power of $828 \mathrm{~kW}$ and a thermal power of $870 \mathrm{~kW}$. A comprehensive description of the Sewage Treatment Plant (STP) and the biogas cogeneration set, together with its basic technical specifications, is provided in $[3,6-8,12,14]$.

The GE JENBACHER JMS 316 GS-B.LC 16-cylinder $\left(\mathrm{V}^{\circ} 0^{\circ}\right)$ turbocharged SI engine $[12,14]$ is a driving unit for the biogas cogeneration set (Fig. 1) that generates electric energy and recovers heat from the engine cooling, lube oil and air-fuel mixture cooling systems and the exhaust-gas heat. This engine drives an AvK DIG $110 \mathrm{i} / 4$ (1090 kVA/864 $\mathrm{kWe} / 6.3 \mathrm{kV} / 1500 \mathrm{~min}^{-1}$ ) self-excited synchronous threephase generator supplied by Cummins Generator Technologies of Germany GmbH [12].

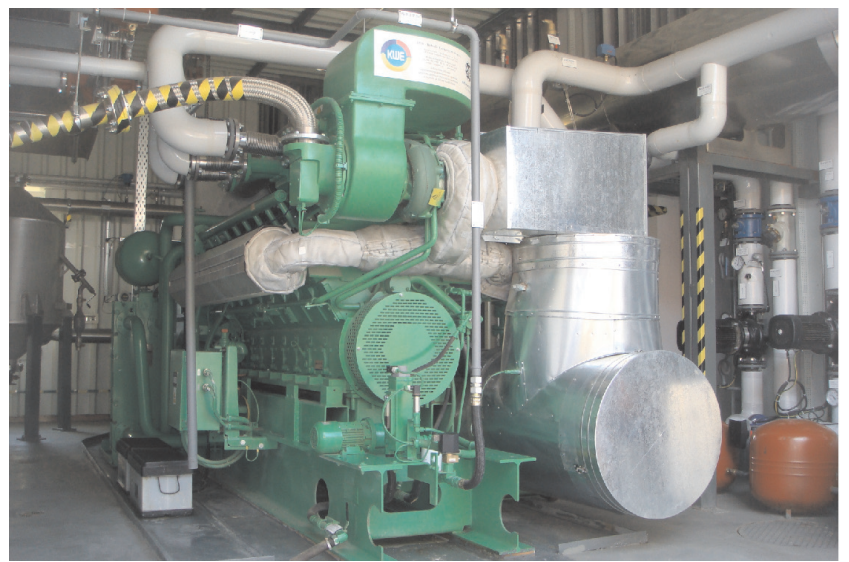

w Polsce GE JENBACHER Gas Engines Division - uruchomiła nowoczesny biogazowy zespół kogeneracyjny z silnikiem GE JENBACHER JMS 316 GS-B.LC o mocy elektrycznej $828 \mathrm{~kW}$ i mocy cieplnej 870 kW. Obszerny opis oczyszczalni ścieków oraz biogazowego zespołu kogeneracyjnego wraz jego danymi technicznymi zawarto w publikacjach [3, 6-8, 12, 14].

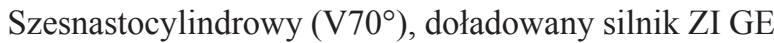
JENBACHER JMS 316 GS-B.LC [12, 14] jest jednostką napędową biogazowego zespołu kogeneracyjnego (rys. 1) wytwarzającego energię elektryczną i odzyskującego ciepło z układów: chłodzenia silnika, oleju smarującego, chłodzenia mieszanki palnej oraz ciepło spalin. Silnik ten napędza samowzbudny synchroniczny generator trójfazowy AvK DIG 110 $\mathrm{i} / 4\left(1090 \mathrm{kVA} / 864 \mathrm{kWe} / 6,3 \mathrm{kV} / 1500 \mathrm{~min}^{-1}\right)$ firmy Cummins Generator Technologies Germany GmbH [12]. Podstawowe dane techniczne zespołu CHP z silnikiem GE JENBACHER JMS 316 GS-B.LC zamieszczono w tabeli 1.

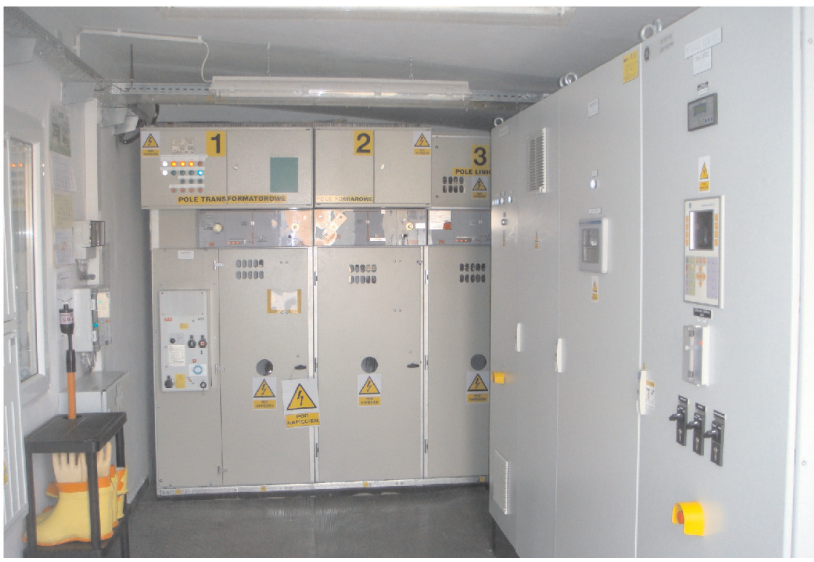

Fig. 1. The biogas cogeneration set with the GE JENBACHER JMS 316 GS-B.LC engine operated at the WARTA S.A. Sewage Treatment Plant of Czestochowa

Rys. 1. Biogazowy zespót kogeneracyjny z silnikiem GE JENBACHER JMS 316 GS-B.LC eksploatowany w Oczyszczalni Ścieków WARTA S.A. $w$ Czestochowie

The basic technical specifications of the biogas cogeneration (CHP) set with the GE JENBACHER JMS 316 GS-B. LC engine are given in Table 1.

Thanks to the use of the LEANOX ${ }^{\circledR}$ air-fuel mixture composition regulation system with a $\mathrm{CO}$ oxidation catalyst and the DIA.NE engine management system, the gas engine meets the exhaust gas emission limits currently applicable to stationary ZI biogas engines, as set out in the TA-Luft 2002 code [10].

The GE JENBACHER JMS 316 GS-B.LC engine gas cogeneration set is fed with biogas of a calorific value of approx. $23 \mathrm{MJ} / \mathrm{m}^{3}$ and an average composition of: $\mathrm{CH}_{4}$ (60-65) \%; $\mathrm{CO}_{2}(30-38) \%$; $\mathrm{H}_{2} \mathrm{~S}(<20 \mathrm{ppm})[3,6-8,23]$. The relatively high $\mathrm{CO}_{2}$ content substantially enhances the antiknock properties of the gas, thus making it an attractive fuel for combustion engines. The required biogas quality [13] is achieved thanks to the use of, among other things, an active carbon filter in the engine fuel system [17].

The electric power of the cogeneration set is controlled either by setting a manual value from the overriding SCADA system level [21, 25] or through automatic operation allow-
Dzięki zastosowaniu systemu regulacji składu mieszanki palnej (LEANOX $\left.{ }^{\circledR}\right)$ z katalizatorem utleniającym $\mathrm{CO}$ i systemu zarządzania silnikiem DIA.NE $[9,12]$ silnik gazowy spełnia aktualnie obowiązujące limity emisji związków toksycznych występujących w spalinach dla stacjonarnych biogazowych silników ZI zawarte w przepisach TA-Luft 2002 [10].

Gazowy zespół kogeneracyjny z silnikiem GE JENBACHER JMS 316 GS-B.LC zasilany jest biogazem o wartości opałowej ok. $23 \mathrm{MJ} / \mathrm{m}^{3}$ i o przeciętnym składzie: $\mathrm{CH}_{4}$ (60-65) \%, $\mathrm{CO}_{2}(30-38) \%, \mathrm{H}_{2} \mathrm{~S}(<20$ ppm) [3, 6-8, 23].

Stosunkowo duża zawartość $\mathrm{CO}_{2}$ w znaczący sposób podnosi odporność przeciwstukową gazu, czyniąc go atrakcyjnym paliwem dla silników spalinowych. Wymagana jakość biogazu [13] osiągana jest m.in. dzięki zastosowaniu w układzie paliwowym silnika filtra z węglem aktywnym [17].

Sterowanie mocą elektryczną zespołu kogeneracyjnego odbywa się przez ręczne zadawanie wartości z poziomu systemu nadrzędnego SCADA [21, 25] lub pracę automatyczną z uwzględnieniem taryfy B23 [26] i stanu napełnienia 
Table 1. Basic technical specifications of the CHP set with GE JENBACHER JMS 316 GS-B.LC engine [12, 14]

Tabela. 1. Podstawowe dane techniczne zespołu CHP z silnikiem GE JENBACHER JMS 316 GS-B.LC [12, 14]

\begin{tabular}{|c|c|c|}
\hline Specification & Unit/jednostka & Value/wartość \\
\hline Ignition type/rodzaj zapłonu & - & $\mathrm{SI}$ - spark ignition/ZI \\
\hline Number of cylinders/liczba cylindrów & - & 16 \\
\hline Engine capacity/objętość skokowa silnika & $\mathrm{dm}^{3}$ & 38.934 \\
\hline Cylinder bore/piston stroke/średnica cylindra/skok ttoka & $\mathrm{mm}$ & $135 / 170$ \\
\hline Compression ratio/stopień sprężania & - & 12.5 \\
\hline Rotational speed - rated/znamionowa prędkość obrotowa & $\min ^{-1}$ & 1500 \\
\hline Average effective pressure/średnie ciśnienie użyteczne & bar & 17.70 \\
\hline Average piston velocity/średnia prędkość ttoka & $\mathrm{m} / \mathrm{s}$ & 8.5 \\
\hline Mechanical output power/moc mechaniczna & $\mathrm{kW}$ & 861 \\
\hline Electric output power $($ at $\cos \varphi=1.00) /$ moc elektryczna $($ przy $\cos \varphi=1.00)$ & $\mathrm{kW}$ & 828 \\
\hline $\begin{array}{l}\text { Air-fuel mixture/water heat exchanger power, } \pm 8 \% \text { level } 1 / \text { level } 2 / \text { moc wymiennika ciepla } \\
\text { mieszanka paliwowo-powietrzna/woda, } \pm 8 \% \text { poziom 1/poziom } 2 /\end{array}$ & $\mathrm{kW}$ & $131 / 38$ \\
\hline Oil/water heat exchanger power, $\pm 8 \% /$ moc wymiennika ciepła olej/woda, $\pm 8 \%$ & $\mathrm{~kW}$ & 95 \\
\hline $\begin{array}{l}\text { Engine cooling warm water/process water heat exchanger power, } \pm 8 \% / \text { moc wymiennika ciepta } \\
\text { plyn chtodzacy silnika/woda technologiczna, } \pm 8 \%\end{array}$ & $\mathrm{~kW}$ & 253 \\
\hline $\begin{array}{l}\text { Exhaust gas/process water heat exchanger power, } \pm 8 \% / \text { moc wymiennika ciepła spaliny/woda } \\
\text { technologiczna, } \pm 8 \%\end{array}$ & $\mathrm{~kW}$ & 391 \\
\hline Total effective thermal power, $\pm 8 \% /$ calkowita moc cieplna, $\pm 8 \%$ & $\mathrm{~kW}$ & 870 \\
\hline Radiation heat/moc promieniowania & $\mathrm{kW}$ & 68 \\
\hline $\begin{array}{l}\text { Electric efficiency of the set/overall efficiency/sprawność elektryczna zestawu/sprawność } \\
\text { ogólna }\end{array}$ & $\%$ & $39.6 / 81.2$ \\
\hline $\begin{array}{l}\text { Engine efficiency loss - per each } 100 \mathrm{~m} \text { of altitude over } 500 \mathrm{~m} \text { above sea level/spadek } \\
\text { sprawności silnika przy zwiększeniu wysokości n.p.m. o } 100 \mathrm{~m} \text { powyżej } 500 \mathrm{~m}\end{array}$ & $\%$ & 0.7 \\
\hline $\begin{array}{l}\text { Engine efficiency loss - per } 1{ }^{\circ} \mathrm{C} \text { above } 25^{\circ} \mathrm{C} / \text { spadek sprawności silnika przy zwiększeniu } \\
\text { temperatury otoczenia o } 1{ }^{\circ} \mathrm{C} \text { powyżej } 25^{\circ} \mathrm{C}\end{array}$ & $\%$ & 0.5 \\
\hline Oil working pressure/robocze ciśnienie oleju & bar & $4-5$ \\
\hline $\begin{array}{l}\text { Cooling water temperature on exit from the engine at full load/temp. plynu chłodzacego na } \\
\text { wyjściu z silnika przy petnym obciqżeniu }\end{array}$ & ${ }^{\circ} \mathrm{C}$ & 90 \\
\hline $\begin{array}{l}\text { Dry/wet engine / CHP set mass/masa silnika bez plynów eksploatacyjnych/z plynami eksploata- } \\
\text { cyjnymi/zestawu CHP }\end{array}$ & $\mathrm{kg}$ & 4000/4490/10 900 \\
\hline Engine/CHP set length/dlugość silnika/zestawu CHP & $\mathrm{mm}$ & $2860 / 5882$ \\
\hline Engine/CHP set width/szerokość silnika/zestawu CHP & $\mathrm{mm}$ & $1340 / 1958$ \\
\hline Engine/CHP set height/wysokość silnika/zestawu CHP & $\mathrm{mm}$ & $1800 / 2240$ \\
\hline Operational oil consumption/jednostkowe zużycie oleju smarującego & $\mathrm{g} / \mathrm{kWh}$ & 0.2 \\
\hline $\begin{array}{l}\mathrm{NO}_{x} / \mathrm{CO} \text { emission (dry exhaust gas at } 5 \% \mathrm{O}_{2}-\text { with } 50 \% \text { load)/emisja } \mathrm{NO}_{x} / \mathrm{CO} \text { (spaliny suche } \\
\text { zawierajace } 5 \% \mathrm{O}_{2} \text { - obciązenie } 50 \% \text { ) }\end{array}$ & $\mathrm{mg} / \mathrm{m}^{3}$ & $500 / 300$ \\
\hline
\end{tabular}

ing for the tariff B23 [26] and the biogas tank filling state $[7,8]$. In the automatic mode, every 10 minutes the system checks for the biogas tank fill state, while trying to increase the biogas inventory during operation beyond the peak tariff and to operate with the highest possible power in the peak tariff period. Information about which tariff is currently "active" is sent from the SCADA overriding system.

\section{Technical and economical experience gained so far}

The analysis presented below has been made based on the data contained in [11] and concerns a three-year period of intensive commercial operation (2009-2011) of the GE JENBACHER JMS 316 GS-B.LC engine Biogas Cogeneration Set (Table 2). From the time its commissioning, the engine has operated 24986 hours. zbiornika biogazu $[7,8]$. W trybie automatycznym system, co 10 minut, kontroluje stan napełnienia zbiornika biogazu, starając się zwiększyć zapas biogazu w czasie pracy poza taryfą szczytową oraz pracując z możliwie wysoką mocą w czasie taryfy szczytowej. Informacje o tym, która taryfa jest aktualnie aktywna przesyłana jest $\mathrm{z}$ systemu nadrzędnego SCADA.

\section{Dotychczasowe doświadczenia techniczno- eksploatacyjne}

Zamieszczoną poniżej analizę wykonano, opierając się na danych zawartych w publikacji [11] i dotyczy ona trzyletniego okresu intensywnej przemysłowej eksploatacji (20092011) biogazowego zespołu kogeneracyjnego z silnikiem GE JENBACHER JMS 316 GS-B.LC (tab. 2). Silnik od chwili uruchomienia przepracował 24986 godzin. 
Table 2. The annual operation time, shutdowns, start-ups and availability of the GS-B.LC engine Biogas Cogeneration Set - the authors' elaboration based on [11]

Tabela 2. Roczny czas pracy, postoje, rozruchy i dyspozycyjność biogazowego zespołu kogeneracyjnego z silnikiem GE JENBACHER JMS 316 GS-B. LC-opracowanie na podstawie [11]

\begin{tabular}{|l|c|c|c|c|}
\hline Year/rok & $\begin{array}{c}\text { Operation time/ } \\
\text { czas pracy [h] }\end{array}$ & $\begin{array}{c}\text { Shutdowns/ } \\
\text { czas przestoju }[\mathrm{h}]\end{array}$ & $\begin{array}{c}\text { Availability/dostępnośćc } \\
\text { liczba rozruchów }\end{array}$ \\
\hline 2009 & 8258 & 502 & 0.942 & 379 \\
\hline 2010 & 8413 & 347 & 0.961 & 268 \\
\hline 2011 & 8093 & 667 & 0.924 & 401 \\
\hline $\begin{array}{l}\text { Total/On average/ } \\
\text { sumarycznie/średnio }\end{array}$ & 24794 & 1516 & 0.942 \\
\hline
\end{tabular}

The data concerning the last operation time and shutdowns of the GE JENBACHER JMS 316 GS-B.LC engine Biogas Cogeneration Set, the number of its start-ups and its availability, are illustrated in Figures 2 and 3.

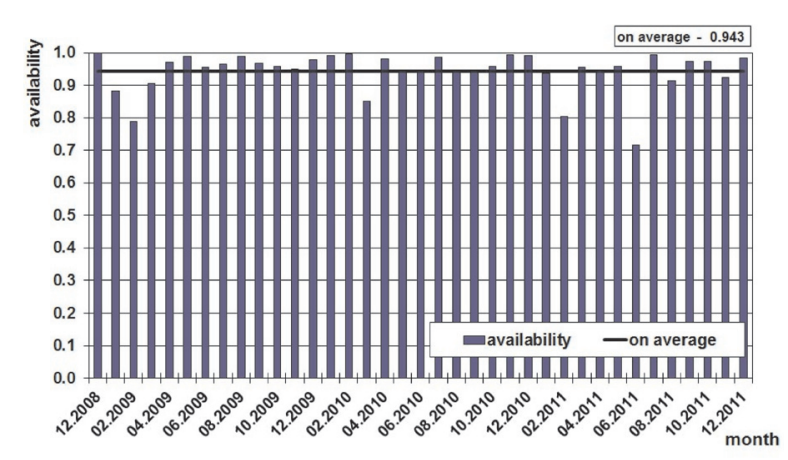

Fig. 2. The availability of the GS-B.LC engine Biogas Cogeneration Set operated in the WARTA S.A. STP of Czestochowa on a monthly basis

Rys. 2. Dyspozycyjność biogazowego zespołu kogeneracyjnego z silnikiem GE JENBACHER JMS 316 GS-B.LC eksploatowanego w OŚ WARTA S.A. w Częstochowie - w ujęciu miesięcznym

Figure 2 above shows that the Biogas Cogeneration Set has been operated in WARTA S.A. Sewage Treatment Plant of Czestochowa very intensively. The Set's average availability of 0.943 , as calculated for the entire last operation period, reflects very well both on the quality of the CHP Set and on the technical services who operate it. In many months, the availability rate approximated the unity. In February 2011, due to a four-day outage caused by a blow-out of the turbocharger and engine housing gasket, the availability rate decreased to 0.8 , while in June 2011 the availability rate reduction down to a level of 0.72 was caused by the planned nine-day servicing of the Cogeneration Set after 20000 hours of its operation.

In February 2009, a total of 142 hours of downtimes of the Cogeneration Set and an increased number (64) of its trips were noted due to disturbances in the external mains (signalization of phases load asymmetry). At the end of 2009, an uncontrolled increase in the number of trips (October-48, November - 36) was noted again, for similar reasons.

The increased number of shutdowns in 2010 (May - 31, June - 54, and August - 30) was due to causes beyond the Operator's control, namely operational shutdowns (inspec-
Dane dotyczące dotychczasowego czasu pracy i postojów biogazowego zespołu kogeneracyjnego z silnikiem GE JENBACHER JMS 316 GS-B.LC, liczby jego rozruchów oraz jego dyspozycyjności zilustrowano na rys. 2 i 3 .

$\mathrm{Z}$ analizy rys. 2 wynika, że biogazowy zespół kogeneracyjny eksploatowany jest w Oczyszczalni Ścieków WARTA S.A. w Częstochowie bardzo intensywnie. Średnia dyspozycyjność zespołu, policzona dla całego dotychczasowego okresu eksploatacji, wynosząca 0,943 bardzo dobrze świadczy zarówno o jakości zespołu CHP, jak i o służbach technicznych, które go eksploatują. W wielu miesiącach wskaźnik ten był bliski jedności. W lutym 2011 r. z powodu czterodniowego postoju, spowodowanego uszkodzeniem uszczelki pomiędzy turbosprężarką a korpusem silnika, obniżył się on do wartości 0,8 , zaś w czerwcu obniżenie tego wskaźnika do poziomu 0,72 spowodowane było planowym - dziewięciodniowym serwisem po 20000 godzinach pracy zespołu kogeneracyjnego.

W lutym 2009 r. zanotowano łącznie 142 godziny postojów zespołu kogeneracyjnego oraz zwiększoną liczbę jego automatycznych wyłączeń (64) z powodu zakłóceń w zewnętrznej sieci elektrycznej (sygnalizacja asymetrii obciążeń faz). W końcu 2009 r., z podobnych przyczyn, wystąpił niekontrolowany wzrost liczby automatycznych wyłączeń (październik - 48, listopad - 36). Zwiększona liczba zatrzymań w 2010 r. (maj - 31, czerwiec - 54 i sierpień - 30) była spowodowana przyczynami niezależnymi od eksploatatora, czyli postojami eksploatacyjnymi (przeglądy, wymiany oleju itp.) oraz pracami konserwacyjnymi sieci zasilających oczyszczalnię i związanymi z tym manewrami przełączeniowymi. Powodem $111 \mathrm{~h}$ postojów w marcu 2010 r. była konieczność wykonania planowego przeglądu po $10000 \mathrm{~h}$ wraz ze zdemontowaniem i regeneracją turbosprężarki w autoryzowanym serwisie.

Przyczyną zwiększonego czasu postoju silnika w lutym 2011 r. (134 h) było prowadzenie prac naprawczych wymiany uszczelki pomiędzy turbosprężarką a korpusem silnika, natomiast czerwcowego (204 h) - planowy serwis zespołu kogeneracyjnego po 20000 godzin jego eksploatacji. Zwiększona liczba rozruchów silnika w lutym 2011 r. (44) spowodowana była następstwem samoczynnych wyłączeń związanych z (trudną do zdiagnozowania) nieszczelnością pomiędzy turbiną a korpusem silnika, zaś w październiku tego samego roku zespół CHP był zatrzymywany aż 92 razy 

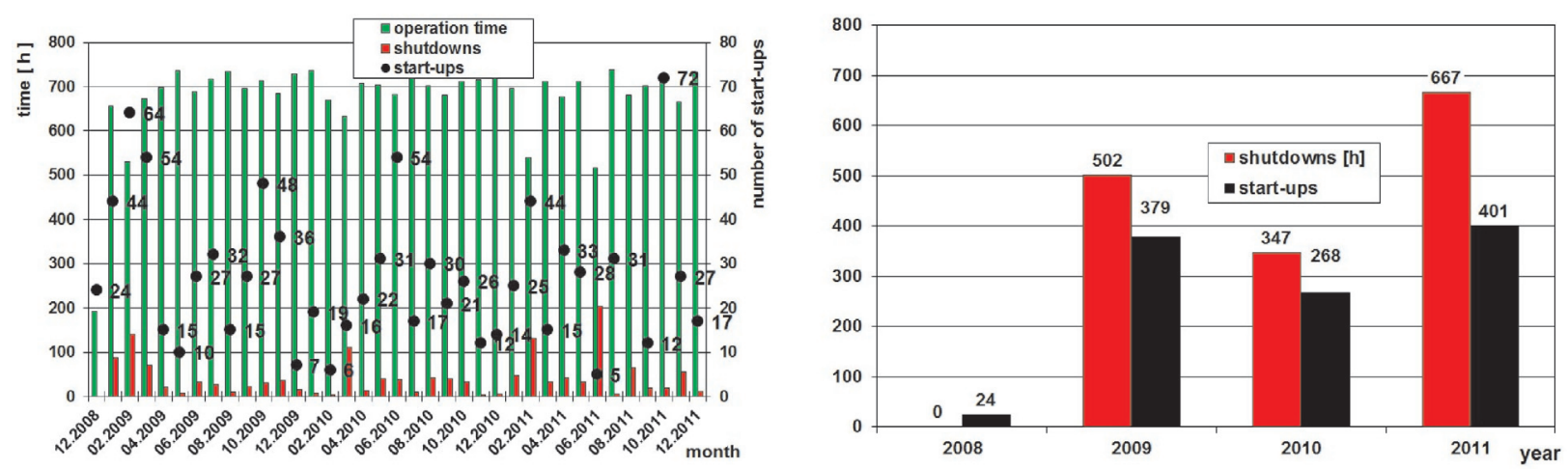

Fig. 3. The operation and shutdown times and the number of start-ups of the GE JENBACHER JMS 316 GS-B.LC engine Biogas Cogeneration Set operated in the WARTA S.A. Sewage Treatment Plant of Czestochowa

Rys. 3. Czas pracy i postojów oraz liczba rozruchów biogazowego zespołu kogeneracyjnego z silnikiem GE JENBACHER JMS 316 GS-B.LC eksploatowanego w OŚ WARTA S.A. w Częstochowie

tions, oil exchanges, etc.) and maintenance work on the Treatment Plant's power supply systems and associated switchover manoeuvres. The cause of the 111 shutdown hours in March, 2010, on the other hand, was the necessity of carrying out the planned 10000 hour inspection involving the dismounting and refurbishment of the turbocompressor at the authorized service centre. The increasedengine downtime in February 2011 (134 h) was the repair work of replacing the turbocompressor and engine housing gasket, while in June (204 h), the planned 20000 hour Cogeneration Set operation maintenance. The increased number of engine start-ups in February (44) was due to the consequences of trips associated with a (difficult to diagnose) leak between the turbocharger and the engine housing. Whereas in October the same year, the CHP set was shut down as many as 92 times due to the necessary training of the operators on the conducting of insular operation of the Cogeneration Set.

The operation time of the GE JENBACHER JMS 316 GS-B.LC engine Biogas Cogeneration Set operated in the WARTA S.A. Sewage Treatment Plant of Czestochowa, z powodu koniecznych szkoleń obsługi związanej z realizacją pracy wyspowej zespołu kogeneracyjnego.

Czas pracy biogazowego zespołu kogeneracyjnego $\mathrm{z}$ silnikiem GE JENBACHER JMS 316 GS-B.LC eksploatowanego w OŚ WARTA S.A. w Częstochowie, produkcję energii elektrycznej i ciepła oraz średnie obciążenia elektryczne i cieplne (wyrażone w MW i odniesione do mocy nominalnych) oraz dyspozycyjność tego zespołu w rozbiciu na poszczególne lata eksploatacji zobrazowano graficznie na rys. 4.

Widoczne na rys. 4 zmniejszenie produkcji energii elektrycznej i ciepła w 2011 r. w stosunku do lat poprzednich spowodowane było m.in. wspomnianym już planowym ponadtygodniowym postojem serwisowym zespołu CHP na przełomie maja i czerwca $2011 \mathrm{r}$. oraz wspomnianym awaryjnym, czterodniowym postojem w lutym 2011 r. Średnie godzinowe obciążenie elektryczne i cieplne biogazowego zespołu CHP w układzie miesięcznym i średnie dla całego dotychczasowego okresu jego eksploatacji przedstawiono na rys. 5.
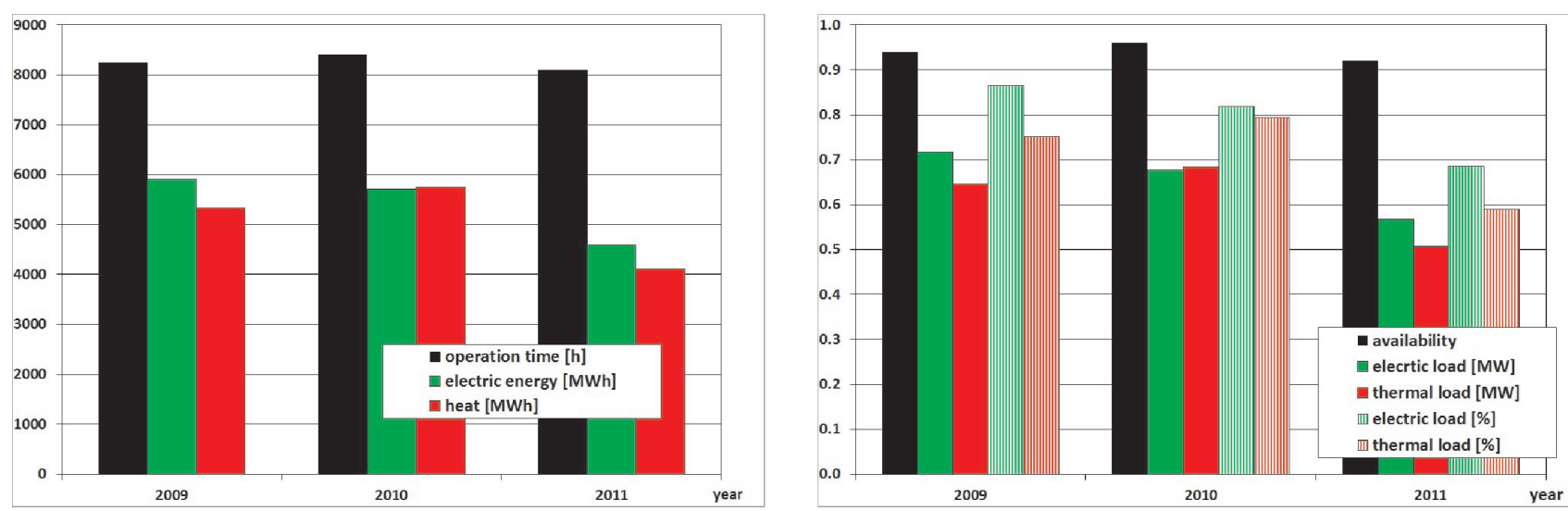

Fig. 4. The operation time of the GE JENBACHER JMS 316 GS-B.LC engine Generation Set operated in WARTA S.A. Sewage Treatment Plant of Czestochowa and the energy and heat generated by the Generation Set, the Generation Set's availability, degree of electric and thermal loading [MW] and relative degree of electric and thermal loading [\% of the rated load] - on a yearly basis

Rys. 4. Czas pracy biogazowego zespołu kogeneracyjnego z silnikiem GE JENBACHER JMS 316 GS-B.LC eksploatowanym w OŚ WARTA S.A. $w$ Częstochowie oraz energia elektryczna i ciepło wyprodukowane przez ten zespót, dyspozycyjność zespolu, stopień obciążenia elektrycznego $i$ cieplnego zespołu [MW], stopień obciażenia elektrycznego i cieplnego zespołu [\% obciázenia nominalnego] - w ujęciu rocznym 
the generation of electric energy and heat, and the average electric and thermal loads (as expressed in MW and referred to the rated powers) and the availability of the Cogeneration Set, as broken down into individual years of operation, are illustrated in Fig. 4.

The visible in Fig. 4 decrease in electric energy and heat generation in 2011 compared to the preceding years was cause, among other things, by the already mentioned over week-long planned maintenance shutdown of the CHP Set at the turn of May and June 2011 and the previously mentioned four-day emergency outage in February 2011. The average hourly electric and thermal load of the CHP Biogas Set as represented on a monthly basis and for the entire previous period of its operation, respectively, is shown in Fig. 5.

The illustration of the monthly electric energy and heat generation and the degree of coverage of the WARTA S.A. STP's internal demands is provided by Fig. 6 .

The data for the coverage of the Czestochowa WARTA S.A. STP's internal demands for electric energy and heat by its own production effected in the Cogeneration Set in successive years of its operation is summarized in Table 3 and illustrated in Fig. 7 and Fig. 8.

Figure 6 indicates that the Czestochowa WARTA S.A. STP's demand for electricity is practically constant during the year, and the electric energy generated by the Biogas Cogeneration Set in the Sewage Treatment Plant covers approx. 50 $\%$ of its demand, in spite of the fact that the STP's production

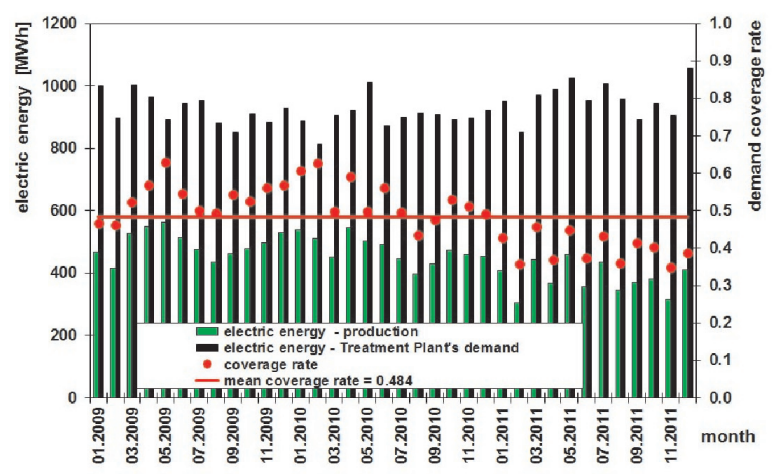

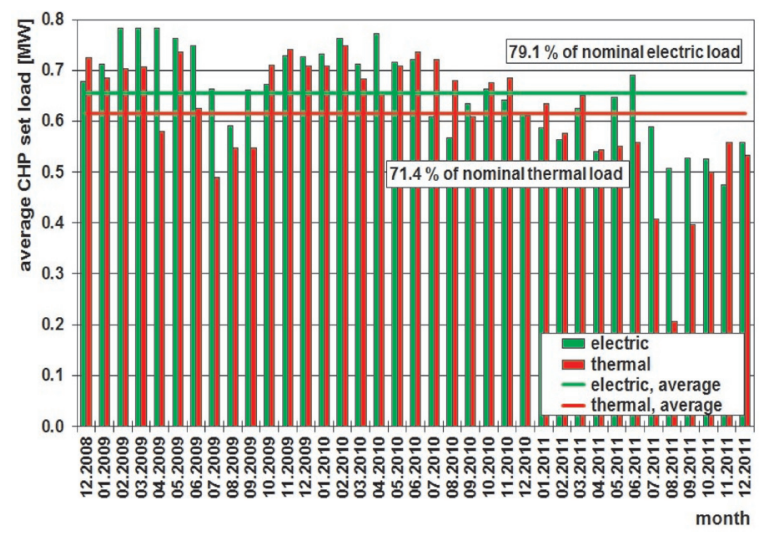

Fig. 5. The average hourly electric and thermal load of the GE JENBACHER JMS 316 GS-B.LC engine Biogas Cogeneration Set operated in the WARTA S.A. Sewage Treatment Plant of Czestochowa

Rys. 5. Średnie godzinowe obciażenie elektryczne i cieplne biogazowego zespolu kogeneracyjnego z silnikiem GE JENBACHER JMS 316 GS-B. LC eksploatowanego w OŚ WARTA S.A. w Częstochowie

Miesięczną produkcję energii elektrycznej i ciepła oraz stopień pokrycia potrzeb własnych OŚ WARTA S.A. tą produkcją przedstawiono na rys. 6 .

Dane odnośnie do pokrycia potrzeb własnych OŚ WARTA S.A. w Częstochowie w zakresie energii elektrycznej i ciepła produkcją własną w biogazowym zespole kogeneracyjnym w kolejnych latach jego eksploatacji podano w tabeli 3 i zobrazowano graficznie na rys. 7 i 8.

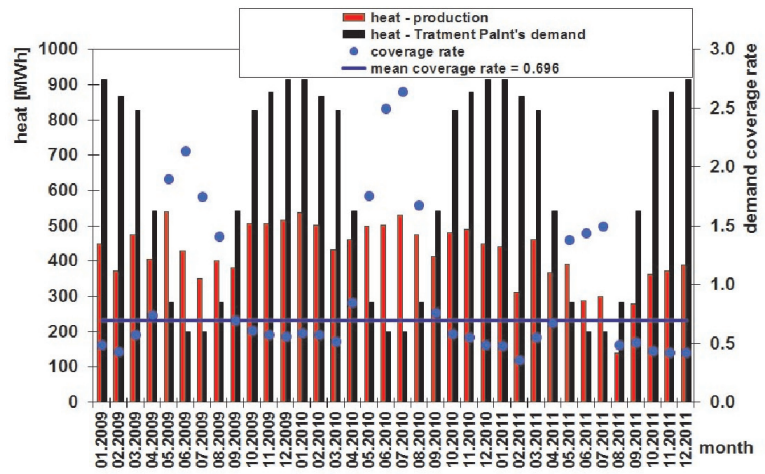

Fig. 6. The electric energy and heat balance of the WARTA S.A. STP (electric energy/heat generated by the Biogas Cogeneration Set, the STP's demand for electric energy/heat and degree of coverage of its demand by its own production)

Rys. 6. Bilans energii elektrycznej i ciepła OŚ WARTA S.A. w Częstochowie (energia elektryczna/ciepło wyprodukowane przez biogazowy zespół kogeneracyjny, zapotrzebowanie oczyszczalni na energię elektryczną/ciepło oraz stopień pokrycia zapotrzebowania produkcją własna)

covered by approx. $20 \%$ less its internal demands in 2011 compared to the two previous years (Fig. 7). The reduction in the output of electricity and heat in 2011 was due to the repair of one of the closed fermentation chamber, which was directly reflected in a lower biogas generation.

The characteristic feature of the Sewage Treatment Plant is a very variable heat demand during the year (Fig. 6). In the winter season, due to the large demand for the process heat necessary for, e.g., heating up of the sewage sludge in closed
Table 3. The coverage of the Czestochowa WARTA S.A. STP's demand for electric energy and heat by its own production in the years 2009-2011- the authors' elaboration based on [11]

Tabela 3. Pokrycie zapotrzebowania OŚ WARTA S.A. w Częstochowie na energię elektryczna i ciepto w latach 2009-2011 produkcją własna - opracowanie na podstawie [11]

\begin{tabular}{|l|c|c|}
\hline \multirow{2}{*}{ Year/rok } & \multicolumn{2}{|c|}{$\begin{array}{r}\text { Demand coverage by own production/pokrycie zapotrzebowania } \\
\text { przez produkcję wtasna }[\%]\end{array}$} \\
\cline { 2 - 3 } & Electricity/prąd elektryczny & Heat/cieplo \\
\hline 2009 & 53.23 & 73.28 \\
\hline 2010 & 52.58 & 79.24 \\
\hline 2011 & 39.93 & 56.37 \\
\hline $2009-2011$ & 48.44 & 69.63 \\
\hline
\end{tabular}



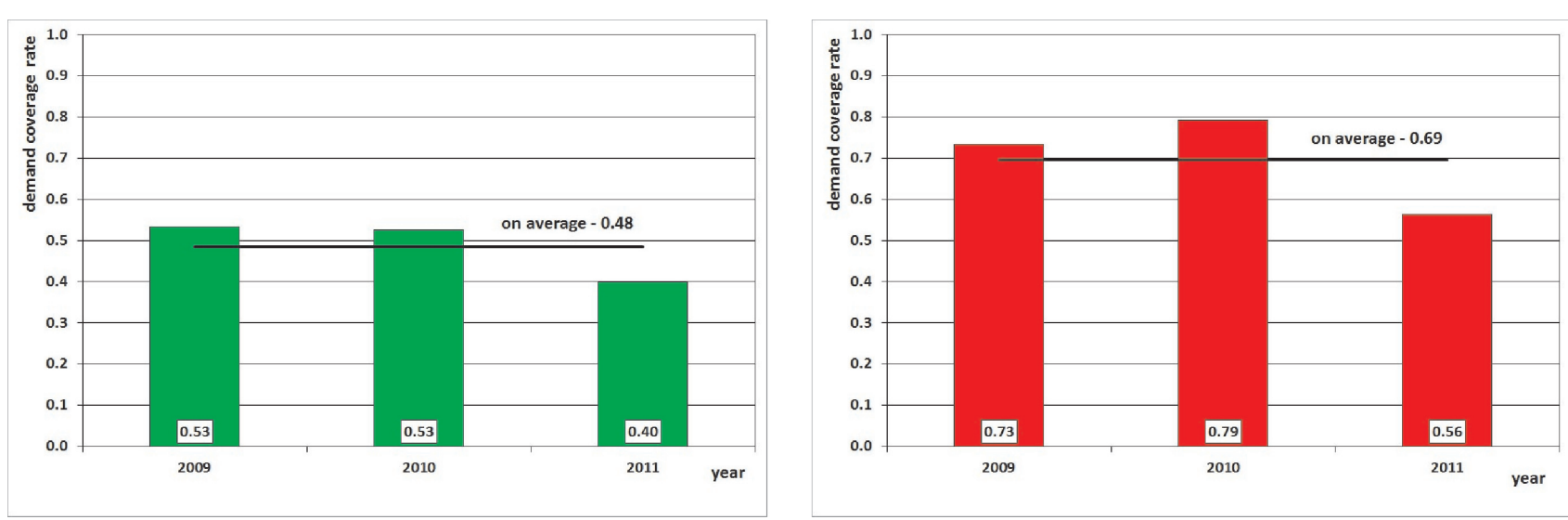

Fig. 7. The degree of coverage of the WARTA S.A. Sewage Treatment Plant's demand for electrical energy and heat in the years $2009-2011$ by its own production in the GE JENBACHER JMS 316 GS-B.LC engine Biogas Cogeneration Set - on an annual basis

Rys. 7. Stopień pokrycia zapotrzebowania OŚ WARTA S.A. w Częstochowie na energię elektrycznq i ciepło w latach 2009-2011 produkcja własna w biogazowym zespole kogeneracyjnym z silnikiem GE JENBACHER JMS 316 GS-B.LC - w ujęciu rocznym

digestion chambers, the generation of heat in the Biogas Set only covers this demand to a small extent (approx. 50 $\%$ ), with the missing part of the heat necessary to cover the STP's internal demands being recovered from the sewage sludge thermal drying process.

In the summer season, the situation is reverse, with a considerable, twofold surplus of generated heat occurring as against the Sewage Treatment Plant's heat demand, and therefore the heat is dissipated in an external table fan cooler installed on the Thermal-Electric Power Station building's roof. During the operation of the Biogas Cogeneration Set so far, the WARTA S.A. STP has been able to utilize approx. 70 $\%$ of the heat generated (recovered) in the CHP Set.

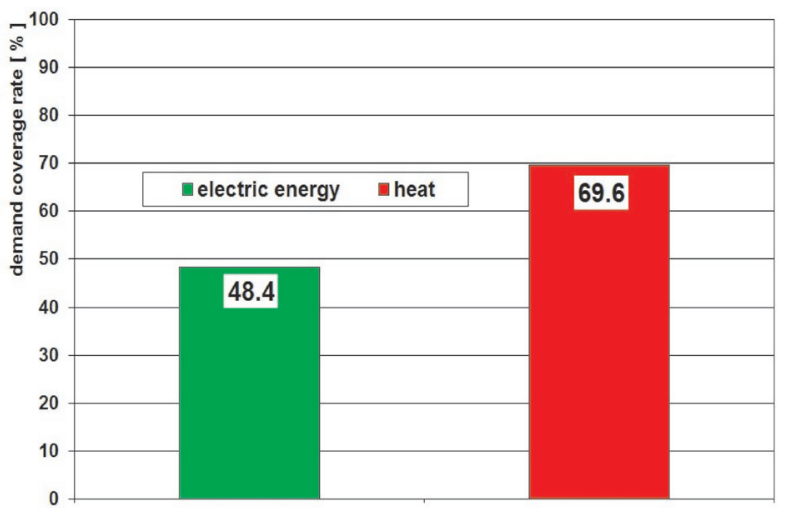

Fig. 8. The average degree of coverage of the WARTA S.A. Sewage Treatment Plant's demand for electrical energy and heat in the years 2009-2011 by its own production in the GE JENBACHER JMS 316 GS-B.LC engine Biogas Cogeneration Set

Rys. 8. Średni stopień pokrycia zapotrzebowania OŚ WARTA S.A. w Częstochowie na energię elektryczna i cieplo w latach 2009-2011 produkcja własna w biogazowym zespole kogeneracyjnym z silnikiem GE JENBACHER JMS 316 GS-B.LC

The average unit biogas consumption by the GE JENBACHER JMS 316 GS-B.LC engine Cogeneration Set in the WARTA S.A. Sewage Treatment Plant of Czestochowa
Z analizy rys. 6 wynika, że zapotrzebowanie OŚ WARTA S.A. w Częstochowie na energię elektryczną jest w ciągu roku prawie stałe i energią elektryczną wyprodukowaną w biogazowym zespole kogeneracyjnym oczyszczalnia pokrywa ok. $50 \%$ swojego zapotrzebowania, pomimo tego iż w 2011 r. produkcją własną pokryto o ok. $20 \%$ mniej potrzeb własnych, w porównaniu do dwóch poprzednich lat (rys. 7). Zmniejszenie produkcji energii elektrycznej i ciepła w 2011 r. spowodowane było remontem jednej z komór fermentacyjnych, co miało bezpośrednie wpływ na mniejszą produkcję biogazu. Specyficzne dla oczyszczalni ścieków jest bardzo zmienne w ciągu roku zapotrzebowanie na ciepło (rys. 6).

W okresie zimowym, ze względu na duże zapotrzebowanie na ciepło technologiczne niezbędne m.in. do podgrzewania osadu w zamkniętych komorach fermentacyjnych, produkcja ciepła w biogazowym zespole pokrywa to zapotrzebowanie jedynie w niewielkim stopniu (ok. $50 \%$ ), a brakujaca część ciepła niezbędna do pokrycia potrzeb własnych oczyszczalni odzyskiwana jest z procesu termicznego suszenia osadu ściekowego. W okresie letnim sytuacja jest odwrotna i występuje znacząca, bo ok. dwukrotna nadwyżka wyprodukowanego ciepła w stosunku do jego zapotrzebowania przez oczyszczalnię i ciepło to jest rozpraszane w zewnętrznej stołowej chłodnicy wentylatorowej zainstalowanej na dachu budynku elektrociepłowni. Podczas dotychczasowej eksploatacji biogazowego zespołu kogenracyjnego OŚ WARTA S.A. była w stanie zagospodarować ok. $70 \%$ ciepła w nim wyprodukowanego (odzyskanego).

Średnie jednostkowe zużycie biogazu przez zespół kogeneracyjny z silnikiem GE JENBACHER JMS 316 GS-B.LC w OŚ WARTA S.A. (rys. 9) policzone dla całego dotychczasowego okresu eksploatacji kształtuje się na dość niskim poziomie i wynosi $0,364 \mathrm{~m}^{3} / \mathrm{kWh}(238,187 \mathrm{~m} / \mathrm{h})$, zaś odniesione do $1 \mathrm{kWh}$ łącznie energii elektrycznej i ciepła - jedynie $0,188 \mathrm{~m}^{3} / \mathrm{kWh}\left(123,020 \mathrm{~m}^{3} / \mathrm{h}\right)$. Analizując to zużycie w poszczególnych latach eksploatacji, można zauważyć niewielką tendencję wzrostową, czego przy- 

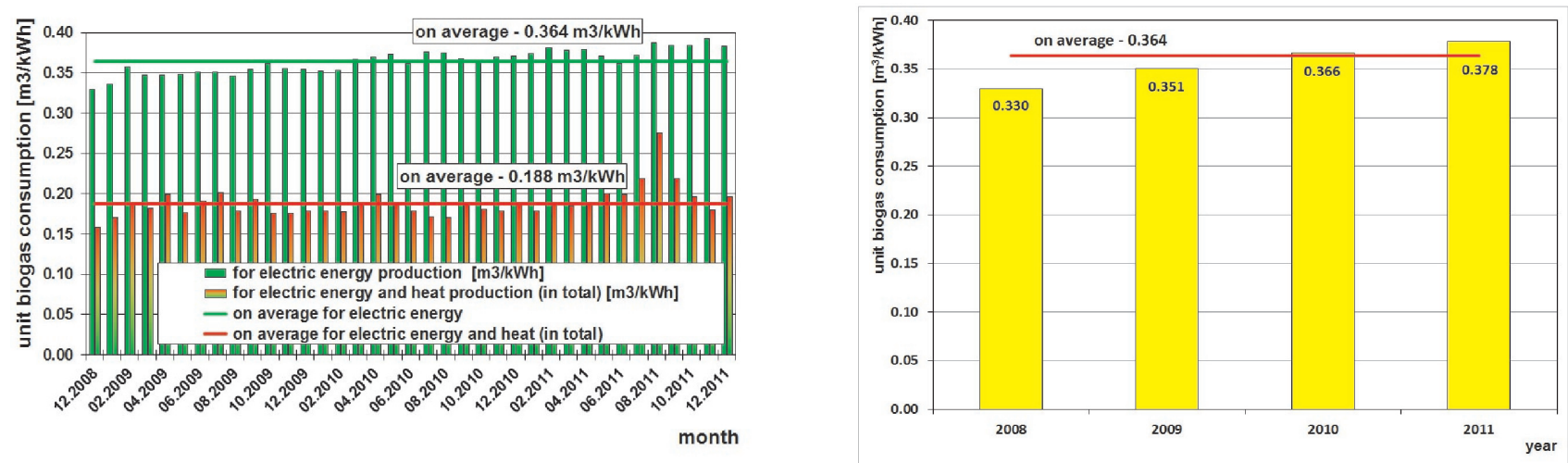

Fig. 9. Unit biogas consumption by the GE JENBACHER JMS 316 GS-B.LC engine Cogeneration Set in the WARTA S.A. STP of Czestochowa on a monthly and an annual basis, respectively

Rys. 9. Jednostkowe zużycie biogazu przez zespót kogeneracyjny z silnikiem GE JENBACHER JMS 316 GS-B.LC w OŚ WARTA S.A. w Częstochowie - w ujęciu miesięcznym i rocznym

(Fig. 9), as calculated for the entire period of operation so far, is at a fairly low level of $0.364 \mathrm{~m}^{3} / \mathrm{kWh}\left(238.187 \mathrm{~m}^{3} / \mathrm{h}\right)$, while as related to $1 \mathrm{kWh}$ of total electricity and heat, it amounts to $0.188 \mathrm{~m}^{3} / \mathrm{kWh}\left(123.020 \mathrm{~m}^{3} / \mathrm{h}\right)$. By analyzing this consumption in particular years of operation, a slight growth trend can be noticed, which is due to the apparent poorer contents of organic components of sewage and the smaller number of hour run by the engine.

\section{Service work}

In their Maintenance Plan set out in [12], the Manufacturer of the GE JENBACHER JMS 316 GS-B.LC engine obliges the Operator to perform all necessary service activities. The Plan covers 60000 hours of Cogeneration Set operation (Fig. 10).

During the recent three-year very intensive operation of the GE JENBACHER JMS 316 GS-B.LC engine Biogas Cogeneration Set, the Operator timely carried out all servicing operations, as required in [12].

The maintenance activities after the initial start-up and then according to the Maintenance Schedule, i.e. every 2000 hrs, have been carried out. The scope of all $2000 \mathrm{~h}$ operation inspections carried out so far included: checking and adjustment of valve clearances, checks of the ignition system, and the inspection of the of the gas path (biogas pressure regulation), the mixer adjustment linkage, the external table cooler, the electric generator, and venting control of the gas engine's crankcase.

The $10000 \mathrm{~h}$ inspection has been additionally extended to cover the refurbishment of the turbocompressor, the exchange of engine cooling water pump, checking of the starter, and the maintenance of the gas mixer.

The last largest of the planned engine inspections - after running $20000 \mathrm{hrs}$ by the engine - took place in the period from 31 May 2011 to 8 June 201 and included also: engine cooling water pump replacement, mixture bypass valve and switch cabinet checking.

So far, the Cogeneration Set Operator has essentially encountered two major technical problems. czyną jest mniejsza zawartość składników organicznych w ściekach oraz mniejsza liczba godzin przepracowanych przez silnik.

\section{Prace serwisowe}

Producent silnika GE JENBACHER JMS 316 GS-B. LC w planie konserwacji zamieszonym w publikacji [12] narzuca eksploatatorowi wszystkie konieczne do wykonania czynności obsługowe. Plan obejmuje 60000 godzin pracy zespołu kogeneracyjnego (rys. 10).

Podczas dotychczasowej-trzyletniej - bardzo intensywnej eksploatacji biogazowego zespołu kogeneracyjnego $\mathrm{z}$ silnikiem GE JENBACHER JMS 316 GS-B.LC eksploatator wykonywał terminowo wszystkie wymagane w dokumentacji [12] czynności serwisowe.

Wykonano konserwację po pierwszym uruchomieniu oraz według harmonogramu konserwacji, tj. co 2000 h. Zakres wszystkich dotychczasowych wykonywanych przeglądów co 2000 h pracy obejmował: sprawdzenie i regulację luzów zaworowych, sprawdzenie instalacji zapłonowej, kontrolę: ścieżki gazowej (regulacji ciśnienia biogazu), mechanizmu dźwigniowego regulacji mieszalnika, zewnętrznej chłodnicy stołowej, generatora elektrycznego i kontrolę odpowietrzenia skrzyni korbowej silnika gazowego.

Przegląd po $10000 \mathrm{~h}$ rozszerzono dodatkowo o regenerację turbosprężarki, wymianę pompy wody chłodzącej silnik, sprawdzenie rozrusznika oraz konserwację mieszacza gazu.

Ostatni największy z planowych przeglądów silnika - po przepracowaniu przez silnik 20000 godzin - nastąpił w okresie od 31.05.2011 r. do 08.06.2011 r. i obejmował ponadto: wymianę pompy wody chłodzącej silnik, kontrolę zaworu obejściowego mieszanki oraz szaf rozdzielczych.

Dotychczas eksploatator biogazowego zespołu kogeneracyjnego zetknął się zasadniczo z dwoma poważniejszymi problemami technicznymi. Pierwszy wynikał z zakłóceń w zewnętrznej sieci elektrycznej (sygnalizacja asymetrii obciążeń faz), drugi - związany był bezpośrednio z uszkodzeniem regulatora $\cos \varphi$. Usterka ta była trudna do zdiagnozowania. 


\begin{tabular}{|c|c|c|c|c|c|c|c|c|c|c|c|c|c|c|c|c|c|c|}
\hline \multirow{3}{*}{ 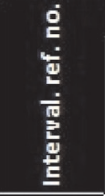 } & \multirow{3}{*}{$\begin{array}{r}\text { Interval reference number }=\text { Operating hours } / 1000 \\
\text { Maintenance task/Inspection task }\end{array}$} & \multirow{3}{*}{ Number } & \multicolumn{16}{|c|}{ ZK $=$ on the occasion of cyliner head dissembly } \\
\hline & & & \multicolumn{16}{|c|}{ Operating hours } \\
\hline & & & 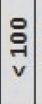 & & & : & ถัํํ & & & \%े & 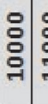 & 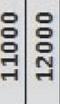 & 울 & ○े & : & : & 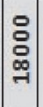 & ذ্సి \\
\hline - & Maintenance after first start-up & W 10000 & & & & & & & & & & & & & & & & \\
\hline 2 & Valve clearance & W $0400 \mathrm{MO}$ & & & & & & & & & & & & & & & & \\
\hline 2 & Ignition system & W $0303 \mathrm{Mo}$ & & & & & & & & & & & & & & & & \\
\hline 2 & Inspection & 101030 & & & & & & & & & & & & & & & & \\
\hline 2 & Table cooler & W 8065 A0 & & & & & & & & & & & & & & & & \\
\hline $2 / 20$ & Crankcase vent & W $0505 \mathrm{M} 0$ & & & & & & & & & & & & & & & & \\
\hline $2 / 30$ & Regulating rods/Throttle valve/Actuator & W $0200 \mathrm{MO}$ & & & & & & & & & & & & & & & & \\
\hline $2 / 30 / 60$ & Gas train & W 8045 A0 & & & & & & & & & & & & & & & & \\
\hline 10 & Turbocharger & W 8023м0 & & & & & & & & & & & & & & & & \\
\hline 10 & Engine coolant pump & W $0201 \mathrm{M} 3$ & & & & & & & & & & & & & & & & \\
\hline 10 & Starter & W $8032 \mathrm{Mo}$ & & & & & & & & & & & & & & & & \\
\hline $10 / 20 / 30$ & Gas mixer & W $0704 \mathrm{MO}$ & & & & & & & & & & & & & & & & \\
\hline 20 & Mixture bypass valve & W $0802 \mathrm{M0}$ & & & & & & & & & & & & & & & & \\
\hline 20 & Torsion vibration damper & W $0601 \mathrm{Mo}$ & & & & & & & & & & & & & & & & \\
\hline 20 & GE Jenbacher-switch cabinets & W $8031 \mathrm{~A} 0$ & & & & & & & & & & & & & & & & \\
\hline 30 & Pistion/Pistion cooling & W $8047 \mathrm{Mo}$ & & & & & & & & & & & & & & & & \\
\hline 30 & Connecting rods/Connecting rods bearing shells & W $8048 \mathrm{M0}$ & & & & & & & & & & & & & & & & \\
\hline 30 & Cyliner liner/Scraper ring & W 8049 Mo & & & & & & & & & & & & & & & & \\
\hline 30 & Crankshaft main bearing & W $8050 \mathrm{M0}$ & & & & & & & & & & & & & & & & \\
\hline ZK 30 & Camshaft/Steering parts & W $8052 \mathrm{M0}$ & & & & & & & & & & & & & & & & \\
\hline 60 & Engine oil pump & W $8046 \mathrm{M} 0$ & & & & & & & & & & & & & & & & \\
\hline 60 & Turbocharger after-lubrication pump & W $8054 \mathrm{MO}$ & & & & & & & & & & & & & & & & \\
\hline 60 & Plate-type heat exchanger & W $8043 \mathrm{MO}$ & & & & & & & & & & & & & & & & \\
\hline 60 & Overhaul & W $2100 \mathrm{Mo}$ & & & & & & & & & & & & & & & & \\
\hline ZK & Exhaust gas manifold/Isolation & W $8051 \mathrm{Mo}$ & & & & & & & & & & & & & & & & \\
\hline - & Generator & W $8030 \mathrm{~A} 0$ & & & & & & & & & & & & & & & & \\
\hline - & Elastomer parts & W 80330 & & & & & & & & & & & & & & & & \\
\hline - & Cylinder head replacament & W $8053 \mathrm{M0}$ & & & & & & & & & & & & & & & & \\
\hline
\end{tabular}

Fig. 10. A fragment of the Maintenance Plan for the GE JENBACHER JMS 316 GS-B. biogas engine up to the inspection of the engine after running for 20000 hours [12]

Rys. 10. Fragment planu konserwacji silnika biogazowego GE JENBACHER JMS 316 GS-B. do przegladu silnika po przepracowaniu 20 000 godzin [12]

The first of them was due to a disturbance in the external mains (signalization of phases load asymmetry). The second problem was directly associated with the $\cos \varphi$ regulator. The failure was difficult to diagnose. Change to the governor settings made several times by the KWE-Technika Energetyczna Service did not help; after changing the settings, the system behaved correctly for a few hours, after which the failure recurred. Only the replacement of the faulty governor did restore the failure-free operation of the Cogeneration Set. In February 2011, on the other hand, an unexpected fourday Cogeneration Set outage occurred, which was caused by the need for replacing the demaged gasket between the turbocharger and the engine housing. Besides the abovementioned deficiencies, the Biogas Cogeneration Set did not pose any technical and operational problems to the user.

The GE JENBACHER JMS 316 GS-B.LC biogas engine is operated on MOBIL PEGASUS 610 SAE 40 class oil [20] and is equipped with a system for automatic oil level monitoring and topping up [16]. The biogas engine's Manufacturer has not established any maintenance cyclefor the lube oil. Undertaking any activities, as necessary for the protection and operational safety of the CHP system and its availability, shall be the responsibility of the Operator [12].
Przeprowadzona przez serwis kilkakrotna zmiana nastaw regulatora nic nie pomogła; układ po przeregulowaniu zachowywał się kilka godzin poprawnie, po czym awaria się powtarzała i dopiero wymiana uszkodzonego regulatora przywróciła bezawaryjną pracę zespołu. W lutym $2011 \mathrm{r}$. wystąpił nieprzewidziany czterodniowy postój zespołu, spowodowany koniecznością wymiany uszkodzonej uszczelki pomiędzy turbosprężarką a korpusem silnika. Biogazowy zespół kogeneracyjny oprócz wspomnianych powyżej usterek nie sprawiał użytkownikowi żadnych problemów techniczno-eksploatacyjnych.

Silnik biogazowy GE JENBACHER JMS 316 GS-B.LC eksploatowany jest przy użyciu oleju klasy SAE 40 - MOBIL PEGASUS 610 [20] i jest wyposażony w układ automatycznej kontroli jego poziomu i uzupełniania [16]. Producent silnika biogazowego nie ustalił cyklu konserwacyjnego dla oleju smarującego. Za podejmowanie wszelkich działań niezbędnych do ochrony $\mathrm{i}$ bezpieczeństwa eksploatacyjnego instalacji CHP i jej dyspozycyjności odpowiada jej eksploatator [12]. W związku z powyższym eksploatator regularnie pobiera zgodnie z zaleceniami GE JENBACHER [12] próbki oleju smarującego (co $500 \mathrm{~h}$ pracy silnika) i zleca badanie ich jakości w certyfikowanym laboratorium. 
Table 4. A summary of lube oil exchanges done so far in the GE JENBACHER JMS 316 GS-B.LC engine - the authors' elaboration based on [11]

Tabela 4. Zestawienie dotychczasowych wymian oleju smarującego w silniku GE JENBACHER JMS 316 GS-B.LC - opracowanie na podstawie [11]

\begin{tabular}{|c|c|c|c|}
\hline No. & Oil exchange date/data wymiany oleju & Operation time/czas pracy $[\mathrm{h}]$ & $\begin{array}{c}\text { Operation time since the last exchange/czas pracy } \\
\text { od poprzedniej wymiany oleju }[\mathrm{h}]\end{array}$ \\
\hline 1 & $12 / 03 / 2009$ & 1603 & 1603 \\
\hline 2 & $22 / 05 / 2009$ & 3274 & 1671 \\
\hline 3 & $05 / 08 / 2009$ & 5010 & 1736 \\
\hline 4 & $29 / 10 / 2009$ & 6992 & 1982 \\
\hline 5 & $21 / 01 / 2010$ & 8950 & 1958 \\
\hline 6 & $21 / 04 / 2010$ & 10958 & 2008 \\
\hline 7 & $30 / 06 / 2010$ & 12582 & 1624 \\
\hline 8 & $24 / 09 / 2010$ & 14588 & 2006 \\
\hline 9 & $23 / 12 / 2010$ & 16671 & 2083 \\
\hline 10 & $31 / 03 / 2011$ & 18809 & 2138 \\
\hline 11 & $01 / 06 / 2011$ & 20198 & 1389 \\
\hline 12 & $25 / 08 / 2011$ & 22009 & 1811 \\
\hline 13 & $21 / 11 / 2011$ & 24021 & 2012 \\
\hline \multicolumn{2}{|l|}{ Average time between oil exchanges/średni czas między wymianami oleju $[\mathrm{h}]$} & 1848 \\
\hline
\end{tabular}

Therefore, in accordance with the GE JENBACHER recommendations [12] the Operator regularly (every $500 \mathrm{hrs}$ of engine operation) takes lube oil samples and outsources their quality testingto the Manufacturer-recommended EXXON MOBIL - certified laboratory. During the operation to date, covering 24986 hours of engine operation (as per 31 Dec. 2011), the lube oil has been exchanged three times (each time, in the amount of $300 \mathrm{dm}^{3}$ ) (Tab. 4).

When analyzing the above table it can be stated that the average engine operation time between successive oil exchanges reflects well both on the engine quality and on the technology of preparation of the biogas supplying the engine.

This is confirmed by the actual operational unit consumption of lube oil by the GE JENBACHER JMS 316 GS-B.LC engine that has amounted to $0.164 \mathrm{~g} / \mathrm{kWh}(0.131$ $\mathrm{dm}^{3} / \mathrm{h}$ ) in the entire past CHP Set operation period covering 24986 hours.

In his Instruction IW 0309M0 [12] concerning sparking plug voltage inspection, the engine Manufacturer recommends, for the GE JENBACHER P7.1V6 sparking plugs on which the WARTA S.A. STP Biogas Cogeneration Set is operated, an inter-electrode gap of $0.35 \mathrm{~mm}$ and an ignition voltage in the range of (12-32) $\mathrm{kV}$. Should these values be exceeded, the adjustment of the sparking plugs or their replacement to new ones will be necessary. One of the methods of reducing the Biogas Cogeneration Set operational cost, especially when the installation is operated without a constant supervision, is to adjust and periodically replace always with the whole (spare) set of 16 sparking plugs, instead of individual sparking plugs. This allows a quick replacement to be made for a set of sparking plugs that have been prior checked (for voltage) and adjusted (for the inter-electrode gap). The Operator regularly performs sparking plug ignition voltage measurements using a FLUKE 123 [22] scopemeter and assures that the voltage values on individual sparking plugs will not exceed the value of $25 \mathrm{kV}$, and should higher
Podczas dotychczasowej eksploatacji obejmującej 24986 godzin (stan 31.12.2011 r.) pracy silnika olej smarujący (w ilości po $300 \mathrm{dm}^{3}$ ) wymieniono trzynastokrotnie (tab. 4).

Analizując powyższą tabelę, należy uznać, iż stosunkowo długi średni czas pracy silnika pomiędzy kolejnymi wymianami oleju dobrze świadczy zarówno o jakości silnika, jak i o technologii przygotowania biogazu zasilającego ten silnik. Potwierdzeniem tego jest eksploatacyjne, jednostkowe zużycie oleju smarującego przez silnik GE JENBACHER JMS 316 GS-B.LC, które w całym dotychczasowym okresie eksploatacji zespołu CHP obejmującym 24986 h pracy wyniosło $0,164 \mathrm{~g} / \mathrm{kWh}\left(0,131 \mathrm{dm}^{3} / \mathrm{h}\right)$.

Producent silnika w Instrukcji IW 0309M0 zawartej w [12] dotyczącej kontroli napięcia świec zapłonowych zaleca dla świec GE JENBACHER P7.1V6, na których eksploatowany jest biogazowy zespół kogeneracyjny w OŚ WARTA S.A. odstęp międzyelektrodowy $0,35 \mathrm{~mm}$ i napięcie zapłonu zawarte w przedziale $(12-32) \mathrm{kV}$. W razie jego przekroczenia konieczne jest ich czyszczenie, regulacja lub ich wymiana na nowe. Jednym ze sposobów zmniejszenia kosztu eksploatacji biogazowego zespołu kogeneracyjnego, zwłaszcza w sytuacji eksploatacji instalacji bez stałego nadzoru, jest regulacja i okresowa wymiana zawsze całego kompletu (zapasowego) świec zapłonowych (16 szt.), a nie poszczególnych świec. Pozwala to na szybką wymianę kompletu, wcześniej sprawdzonych (napięcie) i wyregulowanych (odstęp międzyelektrodowy) świec zapłonowych. Eksploatator regularnie dokonuje pomiarów ich napięcia zapłonu skopometrem FLUKE 123 [22] i przestrzega, aby napięcia na poszczególnych świecach zapłonowych nie przekraczały wartości $25 \mathrm{kV}$, a w razie stwierdzenia napięć wyższych następuje zatrzymanie silnika jedynie na minimalny czas niezbędny do wymiany kompletu świec zapłonowych na zapasowe. Okres między wymianami świec zapłonowych (do ich czyszczenia i regulacji) w warunkach częstochowskiej 
voltages be found, the engine will be shut down only for a minimum period of time as necessary for the set of sparking plugs to be exchanged for a spare one. The time interval between the successive replacements of sparking plugs (to be cleaned and adjusted) under the conditions of the Czestochowa Sewage Treatment Plant does not exceed 3 weeks. The Manufacturer estimates the life of the GE JENBACHER P7.1V6 sparking plugs at about 8000 hours of operation. The sparking plug operation life is determined by the biogas quality and the Operator's care of the cleanliness of the electrodes and their periodical adjustment. Over the 36-month period of Cogeneration Set operation, three sparking plug sets have been consumed. The Operator's care of sparking plugs is necessary and understandable, considering the fact that the cost of a single sparking plug is going for around 1700 PLN, and failure-free sparking plug operation is a prerequisite for the trouble-free work of the entire Cogeneration Set and generation of significant profits from its operation.

\section{The economic effectiveness of biogas CHP set operation}

The WARTAS.A. Sewage Treatment Plant of Czestochowa orders electric power totalling 1.5 MW from two independent sources, and additionally a so called safety power of $0.4 \mathrm{MW}$ (should a possible evacuation of the staff and shutting down the technology be necessary) from a third source.

Since the 5th of March, 2009, a billing system for electrical energy generated by the Biogas Cogeneration Set and used wholly for the Sewage Treatment Plant's own purposes has been in use in the WARTA S.A. STP using ZMD405CT standard commercial electric energy meters [24]. The specific feature of this billing system is that generated electric energy is not sold to an external purchaser at a price lower than the price for which the Sewage Treatment Plant would have to purchase to cover its own needs. Thus, considerable charges for electric energy transmission have been avoided. So, the Plant's profit is largely composed of the cost of the considerably more expensive electric energy that has not been purchased from an external supplier. In the billing system, also unidirectional meters are installed, whose purpose is to record any possible energy transferred from the Sewage Treatment Plant to the external power network and to account for it according to the contract concluded with the $\mathrm{ZE}$ (Electricity Board), which takes place occasionally.

In March 2009 the WARTA S.A. STP of Czestochowa implemented also a procedure for the confirmation of generated "green energy" and obtaining "Certificates of Origin" from the Energy Regulation Authority for RES-generated electric energy, which can be profitably sold by the Sewage Treatment Plant at Towarowa Giełda Energii S.A. (Energy Commodity Exchange) $[18,19]$ to enterprises which, in the framework of the Property Rights Market [18] that has been active in Poland since the 28th of December, 2005, have to fulfil the duty imposed on them under the "Energy Law" to obtain "Certificates of Origin" from cogeneration and submit them to the President of the Energy Regulation Authority (URE) to be remitted. In the period from 05/03/2009 to oczyszczalni ścieków nie przekracza 3 tygodni. Producent szacuje trwałość świec zapłonowych GE JENBACHER P7.1V6 na ok. 8000 h pracy. Na ich żywotność wpływa jakość biogazu oraz dbałość eksploatatora o czystość elektrod i ich okresowa regulacja. W okresie 36 miesięcy eksploatacji zespołu kogeneracyjnego zużyto trzy komplety świec zapłonowych. Dbałość eksploatatora o świece zapłonowe jest konieczna i zrozumiała, gdyż koszt pojedynczej świecy zapłonowej wynosi ok. $1700 \mathrm{zl}$, a ich bezawaryjna praca jest gwarancją bezawaryjnej pracy całego zespołu kogeneracyjnego i generacji znaczących zysków z jego eksploatacji.

\section{Efektywność ekonomiczna eksploatacji biogazowego zespołu CHP}

Oczyszczalnia Ścieków WARTA S.A. w Częstochowie zamawia z dwóch niezależnych źródeł moc elektryczną na poziomie 1,5 MW i dodatkowo z trzeciego źródła 0,4 MW tzw. mocy bezpieczeństwa (na wypadek konieczności ewentualnej ewakuacji załogi i wyłączenia technologii).

Od 5 marca 2009 r. działa w OŚ WARTA S.A. system rozliczania energii elektrycznej wyprodukowanej w biogazowym zespole kogeneracyjnym i wykorzystywanej w całości na potrzeby własne oczyszczalni ścieków z wykorzystaniem przemysłowych liczników energii elektrycznej standardu ZMD405CT [24]. Specyfiką tego systemu rozliczeń jest to, iż wyprodukowana energia elektryczna nie jest sprzedawana odbiorcy zewnętrznemu po cenie niższej od tej, po której oczyszczalnia musiałaby taką energię zakupić na pokrycie potrzeb własnych. Uniknięto w ten sposób m.in. znaczących opłat za przesył energii elektrycznej. Tak więc zysk oczyszczalni to w znaczącej części koszt niezakupionej od dostawcy zewnętrznego znacznie droższej energii elektrycznej. W układzie rozliczeń zainstalowane są także liczniki jednokierunkowe, których zadaniem jest rejestracja energii przekazywanej z oczyszczalni do zewnętrznej sieci elektrycznej i jej rozliczanie zgodnie z zawartą umową z ZE, co występuje incydentalnie.

W marcu 2009 r. wdrożono w OŚ WARTA S.A. w Częstochowie procedurę potwierdzania wyprodukowanej „energii zielonej" i uzyskiwania w Urzędzie Regulacji Energetyki „Świadectw pochodzenia” za energię elektryczną wyprodukowaną z OZE. Świadectwa te mogą być korzystnie sprzedawane przez oczyszczalnię na Towarowej Giełdzie Energii S.A. [18, 19], w ramach działającego w Polsce od 28.12.2005 r. Rynku Praw Majątkowych [18], przedsiębiorstwom, które muszą wypełnić narzucony im „Prawem energetycznym” obowiązek uzyskania i przedstawienia do umorzenia Prezesowi URE „Świadectw pochodzenia” z kogeneracji.

Oczyszczalnia Ścieków WARTA S.A. w okresie od 5.03.2009 r. do 31.12.2011 r. uzyskała 34 świadectwa pochodzenia, na $15200 \mathrm{MWh}$ wytworzonej ilości energii elektrycznej, co stanowiło $100 \%$ energii elektrycznej wyprodukowanej w tym okresie. Część uzyskanych świadectw pochodzenia została odsprzedana przez oczyszczalnię na TGE S.A., jednak ich liczba oraz zysk są informacjami poufnymi i stanowią tajemnicę handlową firmy. 
31/12/2011, the WARTA S.A. Sewage Treatment Plant of Czestochowa obtained 34 Certificates of Origin for a total amount of $15200 \mathrm{MWh}$ generated electric energy, which made up $100 \%$ of electric energy produced during that period. Part of the obtained Certificates of Origin were resold by the Sewage Treatment Plant at Towarowa Giełda Energii S.A. (Energy Commodity Exchange); however their exact number and profit are not disclosed, as they constitute the Company's confidential information.

In the period from $05 / 03 / 2009$ to $31 / 12 / 2011,15179.97$ MWh of electric energy produced in the Biogas Cogeneration Set were allocated for the Plant's own purposes, which accounted for $99.41 \%$ of the Cogeneration Set's production.

This way, during this period, the WARTA S.A. Sewage Treatment Plant of Czestochowa covered averagely $48.4 \%$ (a maximum of $63 \%$ in May 2009, and a minimum of $34.9 \%$ in November 2011) of its demands for electric energy by its own production.

From the analysis of the effectiveness of the investment of installing the GE JENBACHER JMS 316 GS-B engine Biogas Cogeneration Set in the WARTA S.A. Sewage Treatment Plant of Czestochowa, whose total cost has amounted to 3.7 million PLN [27], it can be found that the value of the electric energy alone generated in the Cogeneration Set over the three-year operation period to date has already surpassed the investment cost. A more detailed analysis of the economic gains from the CHP Set operation should also consider the value of the CHP Set-generated heat used for the Plant's internal purposes and the Plant's gain from the Certificates of Origin for the CHP Set-generated electric energy, which have been sold at the TGE S.A. (Polish Power Exchange) to enterprises who have to fulfil the duty, imposed on them under the "Energy Law", to obtain "Cogeneration Certificates of Origin" and submit them to the President of the URE (Energy Regulatory Office) to be remitted. This means that the investment under discussion has paid for itself to the Investor in a period much shorter that 3 years, which should be considered a result worth recognition and an example to be followed by other enterprises, especially sewage treatment plants having "free" biogas at their disposal. Such a short investment return period is unique to sewage treatment plants, because a sewage treatment plant has biogas at its disposal, which is a gaseous fuel of practically zero recovery cost, as it is a by-product of anaerobic sewage sludge fermentation and. In addition, the sewage treatment plant is able to utilize a significant part of its generated heat for its own purposes, alongside the electric energy generation (as the heat is recovered), practically not incurring any additional costs of transferring the heat.

\section{Summary}

- The average availability rate of the Biogas Cogeneration Set for its three-year period of operation so far is $94.3 \%$, which means a very intensive and failure-free operation of the Cogeneration Set.

- The Cogeneration Set had run for 24986 hours until 31/12/2011, generating $16338.9 \mathrm{MWh}$ of electric energy and 15 344.3 MWh of heat during that time, with the coverage of the Sewage Treatment Plant's demand for electric
W okresie od 05.03.2009 r. do 31.12.2011 r. przekazano na potrzeby własne oczyszczalni ścieków 15 179,97 MWh energii elektrycznej wyprodukowanej w bigazowym zespole kogeneracyjnym, co stanowiło aż 99,41 \% jego produkcji i pokrywało własną produkcją średnio 48,4 \% (maks. w maju 2009 r. - 63 \%, zaś min. w listopadzie 2011 - 34,9\%) swojego zapotrzebowania.

Analizując efektywność inwestycji polegającej na zainstalowaniu w OŚ WARTA S.A. w Częstochowie biogazowego zespołu kogeneracyjnego z silnikiem GE JENBACHER JMS 316 GS-B., której całkowity koszt wyniósł 3,7 mln zł [27], można stwierdzić, iż wartość samej tylko energii elektrycznej wyprodukowanej przez ten zespół w okresie dotychczasowej trzyletniej eksploatacji przekroczyła już koszt inwestycji. Analizując bardziej szczegółowo zyski ekonomiczne $\mathrm{z}$ eksploatacji zespołu CHP, należałoby uwzględnić jeszcze wartość ciepła w nim wyprodukowanego i zużytego na potrzeby własne oczyszczalni oraz zysk ze sprzedaży przez oczyszczalnię na TGE S.A. świadectw pochodzenia za energię elektryczną w nim wyprodukowaną przedsiębiorstwom, które muszą wypełnić narzucony „Prawem energetycznym” obowiązek uzyskania i przedstawienia do umorzenia prezesowi URE, „Świadectw pochodzenia z kogeneracji”. Wynika $\mathrm{z}$ tego, iż inwestycja ta zwróciła się inwestorowi w okresie znacznie krótszym niż 3 lata, co należy uznać za wynik godny uznania i powinno to być przykładem i zachętą dla innych przedsiębiorstw, a szczególnie oczyszczalni ścieków dysponujących „darmowym” biogazem. Tak szybki okres zwrotu inwestycji jest specyficzny dla oczyszczalni ścieków, gdyż oczyszczalnia ścieków dysponuje paliwem gazowym biogazem - o prawie zerowym koszcie pozyskania, ponieważ jest on produktem ubocznym beztlenowej fermentacji osadu ściekowego, a ponadto oczyszczalnia ścieków jest w stanie - praktycznie nie ponosząc dodatkowych kosztów jego przesyłu - zagospodarować na potrzeby własne znaczącą ilość wyprodukowanego w nim, niejako przy okazji produkcji energii elektrycznej (bo odzyskanego), ciepła.

\section{Podsumowanie}

- Średnia dyspozycyjność biogazowego zespołu kogeneracyjnego w okresie dotychczasowej trzyletniej jego eksploatacji wynosi 94,3 \%, co świadczy o bardzo intensywnej i bezawaryjnej jego eksploatacji.

- Zespół kogeneracyjny przepracował do 31.12.2011 r. 24986 godzin, produkując w tym czasie 16 338,9 MWh energii elektrycznej i 15 344,3 MWh ciepła, a pokrycie zapotrzebowania oczyszczalni na energię elektryczną i ciepło własną produkcją wyniosło w tym czasie odpowiednio ok. $48,4 \%$ i $69,6 \%$.

- Średnie obciążenie elektryczne zespołu kogeneracyjnego podczas dotychczasowej eksploatacji wyniosło 0,655 MW, co stanowiło 79,1 \% jego obciążenia nominalnego, zaś średnie obciążenie cieplne - odpowiednio: 0,615 MW i $71,4 \%$ jego obciążenia nominalnego.

- Średnia produkcja biogazu w Oczyszczalni Ścieków WARTA S.A. w analizowanym okresie kształtowała się na poziomie $255,644 \mathrm{~m}^{3} / \mathrm{h}$, zaś zużycie biogazu przez zespół kogeneracyjny $-238,187 \mathrm{~m}^{3} / \mathrm{h}\left(0,365 \mathrm{~m}^{3} / \mathrm{kWh}\right)$. 
energy and heat by its own production attaining approx. $48.4 \%$ and $69.6 \%$, respectively, in this period.

- The average monthly loading of the Cogeneration Set during the last period of operation was $0.655 \mathrm{MW}$, which accounted for $79.1 \%$ of its rated loading, while the average thermal loading was, respectively, $0.615 \mathrm{MW}$ and $71.4 \%$, of its rated loading.

- The average WARTA S.A. Sewage Treatment Plant's biogas output in the period under analysis was at a level of $255.644 \mathrm{~m}^{3} / \mathrm{h}$, while the Cogeneration Set biogas consumption rate was $238.187 \mathrm{~m}^{3} / \mathrm{h}\left(0.365 \mathrm{~m}^{3} / \mathrm{kWh}\right)$.

- The average unit biogas consumption in the operation period under examination amounted to $0.368 \mathrm{~m}^{3} / \mathrm{kWh}$ of electric energy and $0.188 \mathrm{~m}^{3} / \mathrm{kWh}$ of electric energy and heat (as taken jointly).

- The unit consumption of lube oil by the biogas engine (oil topping up without exchanging - during $24986 \mathrm{hrs}$ of engine operation, $3267.78 \mathrm{dm}^{3}$ of oil were consumed) is estimated at a level of $0.164 \mathrm{~g} / \mathrm{kWh}\left(0.131 \mathrm{dm}^{3} / \mathrm{h}\right)$, while the figure declared by the Supplier in his offer being 0.3 $\mathrm{g} / \mathrm{kWh}$ (up to the first major repair).

- The operation of the GE JENBACHER JMS 316 GS-B.LC engine Biogas Cogeneration Set brings about measurable energy, economic and ecological benefits to the Czestochowa WARTA S.A. STP, by reducing the atmospheric emission of methane-containing biogas (at the source of its generation) practically to zero. This has improved the energy management at the Czestochowa WARTA S.A. STP in terms of both electric energy and heat, as well as the Plant's energy safety, since the Biogas Cogeneration Set is able to operate on an insular basis as a reserve supply source for the most important equipment of the Plant, while maintaining the parameters of the technology.

- As a result of the operation of the Biogas Cogeneration Set, the Czestochowa WARTA S.A. STP's current operational costs have been considerably reduced thanks to: reducing the purchase of electric energy from external suppliers by approx. $50 \%$; the STP becoming totally independent from external heat suppliers; utilizing heat generated in cogeneration for its internal purposes; giving up the purchase of 40 $\mathrm{t}$ /year of Boiler House fuel oil; obtaining the entry in the "green energy" producer list and regularly obtaining from the URE (Energy Regulatory Office) of "Certificates of Origin" for RES-generated electric energy (estimated by the Operator at over $5000 \mathrm{kWh}$ per year), which has a material value at TGE S.A. (Polish Power Exchange). Investment cost has already paid for itself over a very short time, that is during the last three-year operation period, with the real economic benefits gained being measurably reflected in the final price of treating of $1 \mathrm{~m}^{3}$ sewage [15].

- The presented Biogas Cogeneration Set installation, which has been functioning in the Czestochowa WARTA S.A. Sewage Treatment Plant virtually trouble-free for more three years and bringing about measurable benefits to the Company, can make an example to be followed by future investors, especially other sewage treatment plants that recover "cost-free" engine fuel in the form of biogas.
- Średnie jednostkowe zużycie biogazu w analizowanym okresie eksploatacji wyniosło $0,368 \mathrm{~m}^{3} / \mathrm{kWh}$ energii elektrycznej i $0,188 \mathrm{~m}^{3} / \mathrm{kWh}$ energii elektrycznej i ciepła (łącznie).

- Dotychczasowe eksploatacyjne jednostkowe zużycie oleju smarującego silnik biogazowy (uzupełnienia oleju bez wymian - podczas 24986 h pracy silnika zużyto 3267,78 $\mathrm{dm}^{3}$ oleju) kształtuje się na poziomie $0,164 \mathrm{~g} / \mathrm{kWh}(0,131$ $\mathrm{dm}^{3} / \mathrm{h}$ ), zaś deklarowane przez dostawcę - 0,3 g/kWh (do pierwszej naprawy głównej)

- Eksploatacja biogazowego zespołu kogeneracyjnego z silnikiem GE JENBACHER JMS 316 GS-B.LC przynosi OŚ WARTA S.A. w Częstochowie wymierne korzyści energetyczne, ekonomiczne i ekologiczne, redukując prawie do zera (u źródła jego wytwarzania) emisję do atmosfery biogazu zawierającego w swym składzie metan. Poprawiła ona gospodarkę energetyczną OŚ WARTA S.A. zarówno w zakresie energii elektrycznej, jak i ciepła, a także bezpieczeństwo energetyczne oczyszczalni, ponieważ biogazowy zespół kogeneracyjny może pracować „wyspowo”, jako rezerwowe źródło zasilania najistotniejszych urządzeń oczyszczalni z zachowaniem parametrów technologii.

- W wyniku eksploatacji biogazowego zespołu kogeneracyjnego zmniejszono znacząco bieżące koszty eksploatacji OŚ WARTA S.A. w Częstochowie dzięki: ograniczeniu o ok. $50 \%$ zakupu energii elektrycznej od dostawców zewnętrznych, całkowitemu uniezależnieniu się od zewnętrznych dostawców ciepła, zagospodarowywaniu na potrzeby własne całego ciepła wyprodukowanego w kogeneracji, zrezygnowaniu z zakupu oleju opałowego do kotłowni w ilości ok. 40 t/rok, uzyskaniu wpisu na listę producentów „zielonej energii” i regularnemu pozyskiwaniu w URE „Świadectw pochodzenia” energii elektrycznej wyprodukowanej z OZE (szacowanej rocznie przez eksploatatora na ponad $5000 \mathrm{MWh}$ ), mających wartość materialną na TGE S.A. Koszt inwestycji zwrócił się już podczas dotychczasowej bardzo krótkiej, bo dopiero trzyletniej eksploatacji, a uzyskiwane realne korzyści ekonomiczne znajdują wymierne odzwierciedlenie w końcowej cenie oczyszczenia $1 \mathrm{~m}^{3}$ ścieków [15].

- Zaprezentowana instalacja $\mathrm{z}$ biogazowym zespołem kogeneracyjnym funkcjonująca prawie bezawaryjnie od ponad trzech lat w OŚ WARTA S.A. w Częstochowie i przynosząca firmie wymierne korzyści ekonomiczne stanowić może dla przyszłych inwestorów przykład do naśladowania, szczególnie dla innych oczyszczalni ścieków pozyskujących „,bezkosztowo” paliwo silnikowe w postaci biogazu.

This publication was carried out within a project financed from the funds of the National Science Centre, Kraków, Poland.

Publikacja została wykonana $w$ ramach projektu badawczego finansowanego przez Narodowe Centrum Nauki w Krakowie. 


\section{Abbreviations/Skróty i oznaczenia}

CHP Combined Heat and Power/energetyka skojarzona

RES/OZE Renewable Energy Sources/odnawialne źródła energii

SCADA Supervisory Control And Data Acquisition System/ nadrzędny system akwizycji i kontroli danych
STP/OŚ Sewage Treatment Plant/oczyszczania ścieków

TGE S.A. Polish Power Exchange/Towarowa Giełda Energii S.A.

URE Energy Regulatory Office/Urząd Regulacji Energii

ZE Electricity Board/Zaktad Energetyczny

\section{Bibliography/Literatura}

[1] Cupiał K., Dużyński A.: Dorobek Instytutu Maszyn Tłokowych i Techniki Sterowania Politechniki Częstochowskiej w dziedzinie konstrukcji, badań i eksploatacji silników gazowych. Silniki Gazowe - wybrane zagadnienia. Monografia pod red. Dużyńskiego A. Wydawnictwo Politechniki Częstochowskiej, Częstochowa 2010.

[2] Cupiał K., Dużyński A., Grzelka J.: A summary of the eight years of operation of the biogas heat and power-generating set in the Waste Treatment Plant of WARTA S.A. in Częstochowa. Combustion Engines 1/2006 (124).

[3] Cupiał K., Dużyński A., Grzelka J., Bawor W.: Podsumowanie sześciomiesięcznej eksploatacji nowego biogazowego zespołu kogeneracyjnego w Oczyszczalni Ścieków WARTA S.A. w Częstochowie. Współczesne problemy energetyki gazowej i gazownictwa. Monografia pod red. Kaliny J., Kotowicza J., Skorka J., Walewskiego A. Energetyka Gazowa 2009. Wyd. Instytutu Techniki Cieplnej, Gliwice 2009.

[4] Cupiał K., Dużyński A., Grzelka J., Mendera K.: Biogazowy zespół prądotwórczy o mocy elektrycznej $600 \mathrm{~kW}$ z utylizacją ciepła. Journal of KONES - Internal Combustion Engines - Warszawa-Zakopane 1999, vol. 6, nr 3-4, Scientific Publication of Permanent Committee of KONES, Kraków 1999.

[5] Dużyński A.: Analiza rzeczywistych parametrów techniczno-eksploatacyjnych gazowych zespołów kogeneracyjnych. Politechnika Częstochowska, seria Monografie nr 142. Częstochowa 2008.

[6] Dużyński A.: Technological and economic aspects of two year's operation of the biogas cogeneration set at the WARTA S.A. waste treatment plant in Czestochowa, Poland, s. 25-35. Power Engineer. Journal of the IDGTE. Vol. 16, Issue 1, The Institution of Diesel and Gas Turbine Engineers, Bedford, UK, 2012. ISSN-1367-191x.

[7] Dużyński A., Bawor W.: A Summary of the twelve month's operation of the new biogas cogeneration set in the WARTA S.A. Waste Treatment Plan in Częstochowa. Combustion Engines 2/2010 (141)

[8] Dużyński A., Bawor W.: Experience from two years' operation of the Biogas Cogeneration Set at the WARTA S.A.

Adam Dużyński, DEng - Assistant Professor at the Faculty Mechanical Engineering and Computer Science at the Czestochowa University of Technology, Poland.

Dr inż. Adam Dużyński - adiunkt na Wydziale Inżynierii Mechanicznej i Informatyki Politechniki Częstochowskiej.

e-mail: duzynski@imc.pcz.czest.pl
Waste Treatment Plant in Częstochowa. Combustion Engines 3/2011(146).

[9] Elsenbruch T.: GE ENERGY Jenbacher gas engine technology - preventive maintenance by means of highly sophisticated control systems. Combustion Engines 2/2006 (125).

[10] Kalmbach S., Schmölling J.: Technische Anleitung zur Reinhaltung der Luft - TA Luft. TA Luft mit Erläuterungen. Erich Schmidt Verlag GmbH \& Co., Berlin 2004.

[11] Dziennik eksploatacyjny biogazowego zespołu kogeneracyjnego $z$ silnikiem GE JENBACHER JMS 316 GS-B.LC za okres 12.2008-31.12.2011. Materiały wewnętrzne Oczyszczalni Ścieków WARTA S.A. w Częstochowie.

[12] GE JENBACHER Documentation JMS 316 GS-B/LC - wersja 2004.01.

[13] Instrukcja techniczna nr 1000-0300. Jakość gazu pędnego. GE JENBACHER Documentation. 08.2005.

[14] Jenbacher gas engines. Technical Specification. JMS 316 GS-B.L. GE JENBACHER GmbH \& Co. OHG, www.cogeneration.com.ua/img/zstored/J316V21_en.pdf - 09.2011.

[15] Jurajski Produkt Roku. Regionalna Izba Przemysłowo-Handlowa w Częstochowie. Częstochowa 2010. www.blachownia. p1/2011/207-jurajski/jpr2010.pdf - 09.2011.

[16] Modernizacja gospodarki energetycznej i cieplnej z zastosowaniem odnawialnych źródeł energii na centralnej oczyszczalni ścieków eksploatowanej przez Oczyszczalnię Ścieków WARTA S.A. w Częstochowie. Zespół prądotwórczy. Projekt wykonawczy. II. Część technologiczna. BIPROWOD-Warszawa Sp. z o.o. Warszawa, luty 2008 r.

[17] Oczyszczanie gazu absorberami węgla aktywnego - JENBACHER Energie.

[18] Rynek Praw Majątkowych, www.tge.pl; www.polpx.pl, 05.2012 .

[19] www.cire.pl/GE 05.2012.

[20] www.ekonaft.com.pl/mobil_last/przemyslowe-mobil/n06_do silnikow_gazowych/full-mobil-pega-sus610.htm, 06.2009.

[21] www.nergia.rzeszow.pl/index.php?option $=$ com_content\&vie$\mathrm{w}=$ article $\& \mathrm{id}=94$ :systemy-scada- $\mathrm{w}$-sterowaniu-procesamitechnologicznymi\&catid=45: potencja-c-net, 10.2012.

[22] www.fluke.com/fluke/plpl/Portable-Oscilloscopes/Fluke-120. htm?PID=55999, 10.2012 .

[23] www.fresenius-ut.com/download/DB_BIOGASv2.pdf, 10.2012.

[24] www.landis.com, 09.2012.

[25] www.plcs.net.pl/index.php/nowosci-ze-swiata-automatyki/ praktyczne-rozwiazania-automatyki/systemy-scada-wstep. html, 10.2012.

[26] www.tauron-dystrybucja.pl/r/res/taryfa/Taryfa_TAURON_ Dystrybucja_2012.pdf, 05.2012.

[27] www.wartasa.eu, 01.2012. 